\title{
Electrophoretic and Immunochemical Study of the Lipopolysaccharides Produced by Chemostat-grown Escherichia coli 0157
}

\author{
By KAREN L. DODDS, * MALCOLM B. PERRY AND \\ IAN J. MCDONALD \\ Division of Biological Sciences, National Research Council of Canada, Ottawa, \\ Ontario KlA OR6, Canada
}

(Received 20 January 1987; revised 22 April 1987)

Two chemically different $O$-polysaccharides, a low molecular mass form of LPS and core LPS produced by chemostat-grown $E$. coli O157, were analysed by SDS-PAGE, silver staining and immunoblotting. The reactivities of the different $O$-polysaccharides with antisera prepared against E. coli $\mathrm{O} 157$ grown in batch culture, Salmonella $\mathrm{O} 30$ or Brucella abortus were very similar, showing that the $O$-polysaccharides share at least some antigenic determinants. The reactions of the low molecular mass LPS with the antisera indicated it was semi-rough LPS having one repeat unit of the $O$-polysaccharide attached to core LPS.

\section{INTRODUCTION}

The serotype-specific antigens of smooth strains of Gram-negative bacteria are carried on the lipopolysaccharide (LPS) of their outer membrane, specifically on the $O$-polysaccharide portion of the molecule. Structural studies of LPS have helped to determine the molecular basis of serological classifications and reactivities. The serological cross-reactions which occur between Escherichia coli $\mathrm{O} 157$, Brucella abortus, Yersinia enterocolitica $\mathrm{O} 9$ and Vibrio cholerae strains have been related to the presence of $1 \rightarrow 2$-linked 4-amino-4,6-dideoxy- $\alpha$-D-mannopyranose (D-perosamine) residues in the $O$-polysaccharide repeating unit of their LPSs (Perry et al., 1986).

E. coli O157, grown using chemostat culture, produces different forms of LPS depending on the growth rate and growth-limiting nutrient (Dodds et al., 1987). At a high growth rate $\left(D=0.8 \mathrm{~h}^{-1}\right.$, doubling time $\left(t_{\mathrm{d}}\right)$ approx. $\left.52 \mathrm{~min}\right), E$. coli $\mathrm{O} 157$ produced a very small amount of $O$-polysaccharide which was different from the $O$-polysaccharide previously characterized in that it lacked 2-aminohexose. Perry et al. (1986) identified the phenol-phase LPS from $E$. coli O157 grown in batch culture as a linear polysaccharide having the structure $[\rightarrow 3)-\alpha-D-G a l N A c p-$ $(1 \rightarrow 2)-\alpha$-D-PerNAc $p-(1 \rightarrow 3)-\alpha-L-F u c p-(1 \rightarrow 4)-\beta$-D-Glc $p-(1 \rightarrow]_{n}$ which tests positively for 2-aminohexose. The exceedingly small amount of $O$-polysaccharide (1-2 mg purified from $100-150 \mathrm{mg}$ of LPS) produced at the high growth rate has made chemical studies difficult. The predominant form of LPS produced by $E$. coli $\mathrm{O} 157$ at the high growth rate was of low molecular mass.

The immunoblotting technique has been used to study the interactions between antibodies and SDS-PAGE separated LPSs, improving the characterization of LPS (Chart et al., 1984; Dooley et al., 1985; deJongh-Leuvenink et al., 1985). In this paper, we report results of studies on the different forms of LPS produced by $E$. coli 0157 by using electrophoresis and immunoblotting with sera prepared against E. coli $\mathrm{O} 157$ (grown in batch culture), B. abortus and Salmonella $\mathrm{O} 30$.

\section{METHODS}

Bacteria and growth conditions. E. coli 0157:H7 (LCDC 82-1933, NRCC 4125) was obtained from the Laboratory Centre for Disease Control, Health and Welfare Canada. Cells were grown in chemostats as continuous cultures in a glucose-mineral salts medium with either glucose $\left(1 \mathrm{~g} \mathrm{l}^{-1}\right)$ or $\mathrm{Mg}^{2+}(5 \mathrm{mg}$ $\mathrm{MgCl}_{2} .6 \mathrm{H}_{2} \mathrm{O}^{-1}$ ) as the limiting nutrient as described previously (Dodds et al., 1987). The dilution rates used were 
$0 \cdot 1,0.4$ and $0.8 \mathrm{~h}^{-1}$, corresponding to mean $t_{\mathrm{d}}$ values of 416,104 and $52 \mathrm{~min}$, respectively. At each dilution rate the culture was allowed to equilibrate for at least seven mass doublings before collection of cells from the effluent port into aqueous phenol $(0.5 \%, \mathrm{w} / \mathrm{v}$, final concentration) was started.

Cells were concentrated using the Pellicon Cassette system equipped with Durapore $0 \cdot 22 \mu \mathrm{m}$ separators (Millipore), harvested by centrifugation, washed with a solution of $2 \%(\mathrm{w} / \mathrm{v}) \mathrm{NaCl}$ in $0.5 \%$ phenol and stored at $5^{\circ} \mathrm{C}$ until used for LPS extractions.

LPS extraction. The hot phenol-water procedure was used to extract LPS from cells (Westphal \& Jann, 1965). The extracts from the water and phenol phases were each taken up in $1 \% \mathrm{NaCl}$ and LPS was pelleted by ultracentrifugation $\left(105000 \mathrm{~g}, 4{ }^{\circ} \mathrm{C}, 16 \mathrm{~h}\right)$. The pellets were dissolved in water and lyophilized. Ultracentrifugation was repeated until LPS preparations gave a single sharp peak at $460 \mathrm{~nm}$ in the carbocyanine dye assay (Johnson \& Perry, 1976) and no measurable absorption peaks in the UV region $(310-200 \mathrm{~nm})$.

$S D S-P A G E$. Purified LPS samples $(10 \mu \mathrm{g})$ or the LPS of proteinase-K digested whole cells (Hitchcock \& Brown, 1983) were analysed by electrophoresis in duplicate $1.5 \mathrm{~mm}, 14 \%(\mathrm{w} / \mathrm{v})$ polyacrylamide gels using the system described by Laemmli (1970). Purified LPS from B. abortus 1119-3, Pasteurella hemolytica serotype 4 and Salmonella adelaide, which have respectively, monosaccharide, disaccharide and pentasaccharide repeating units in their $O$ polysaccharide, were used as standards (Perry \& Babiuk, 1984). The current was set at $15 \mathrm{~mA}$ per gel until the tracking dye was through the stacking gel, and then at $35 \mathrm{~mA}$ per gel until the dye was $10 \mathrm{~cm}$ into the separating gel. One gel was fixed and stained using the silver stain of Tsai \& Frasch (1982), while the duplicate gel was used for immunoblotting.

Antisera. Antisera raised against E. coli $\mathrm{O} 157$ grown for $18 \mathrm{~h}$ at $37^{\circ} \mathrm{C}$ in Brain Heart Infusion broth (Difco) was kindly provided by D. W. Griffith, and was prepared as follows. Rabbits were inoculated intravenously with a freshly prepared suspension of formalin-killed $E$. coli $\mathrm{O} 157$ in $0.85 \% \mathrm{NaCl}$ containing $2 \times 10^{9} \mathrm{cells} \mathrm{ml}^{-1}$. At $4 \mathrm{~d}$ intervals the rabbits were injected with increasing amounts $(0.5,1.0,2.0$ and $3.0 \mathrm{ml})$ of the antigen suspension. The antisera were collected $8 \mathrm{~d}$ after the last injection.

Anti-Salmonella $\mathrm{O} 30$ rabbit serum was obtained from Wellcome. Anti-B. abortus serum was prepared by immunization of cows with formalin-killed B. abortus 1119-3 (Caroff et al., 1984).

Immunoblotting. LPS from polyacrylamide slab gels was transferred to nitrocellulose sheets (Bio-Rad) using the transfer buffer of Towbin et al. (1979) and a Trans-Blot Electrophoretic Cell (Bio-Rad) by electroblotting overnight at $30 \mathrm{~V}$ and $0.1 \mathrm{~A}$. Subsequent silver staining of the polyacrylamide gel showed that, while transfer of LPS was not complete, there was no visible difference in transfer of the various LPSs. Unreacted sites on the nitrocellulose sheets were blocked with $3 \%(\mathrm{w} / \mathrm{v})$ gelatin in $20 \mathrm{~mm}$-Tris/ $/ \mathrm{HCl} \mathrm{pH} 7.5$ containing $0.5 \mathrm{M}-\mathrm{NaCl}$ (TBS) for $60 \mathrm{~min}$. The nitrocellulose sheets were washed twice for $10 \mathrm{~min}$ with $0.05 \%(\mathrm{w} / \mathrm{v}) \mathrm{Tween} 20$ in TBS (TTBS) before overnight incubation with the species-specific first antibody diluted $1: 1000$ in $1 \%(\mathrm{w} / \mathrm{v})$ gelatin-TTBS. Unbound antibodies were removed by washing the sheets three times for $10 \mathrm{~min}$ each with TTBS. The sheets were then incubated for $2 \mathrm{~h}$ with the appropriate horse-radish peroxidase (HRP) conjugated immunoglobulin diluted $1: 3000$ in $1 \%$ gelatin-TTBS, before being washed three times for $10 \mathrm{~min}$ each with TTBS and once for $10 \mathrm{~min}$ with TBS. Finally, sheets were incubated for $30 \mathrm{~min}$ with a colour development solution containing 4-chloro-1-naphthol prepared according to the manufacturer's instructions (Bio-Rad).

The second antibodies used were affinity-purified goat anti-rabbit IgG HRP conjugate (Bio-Rad) and chromatographically-purified rabbit anti-cow immunoglobulins HRP conjugate (Dakopatts).

Absorption of antiserum. E. coli $\mathrm{O} 157$ was grown in L-broth for $18 \mathrm{~h}$ at $37^{\circ} \mathrm{C}$. Bacteria were harvested by centrifugation, washed and resuspended in TBS to an $\mathrm{OD}_{660}$ of $0 \cdot 6$. Cell suspension ( $5 \mathrm{ml}$ ) was added to anti-E. coli sera diluted 1:1000 in $50 \mathrm{ml}$ of 1\% gelatin-TBS. This mixture was incubated at room temperature for $1 \mathrm{~h}$. Cells were removed by centrifugation at $12000 \mathrm{~g}$ for $10 \mathrm{~min}$. The efficiency of absorption of the antiserum was monitored using proteinase-K digested cells which had been grown in L-broth for $18 \mathrm{~h}$ at $37^{\circ} \mathrm{C}$.

\section{RESULTS}

Analysis by SDS-PAGE (Fig. $1 a$ ) showed the various forms of LPS produced by $E$. coli O157 grown under different conditions as established previously (Dodds et al., 1987). Although LPS was present in both the aqueous and phenol phases after hot phenol-water extraction of cells, the phenol phase preferentially extracted high molecular mass LPS and, by comparison with the LPS of proteinase-K digested whole cells, was shown to be representative of the LPS produced by cells grown at low growth rates or in batch culture. The aqueous phase contained more low molecular mass LPS and was representative of the LPS produced by cells grown at high growth rates (Dodds et al., 1987). Phenol-phase LPS from C-limited or $\mathrm{Mg}^{2+}$-limited cells grown at $D=0.1$ or $0.4 \mathrm{~h}^{-1}$ showed high molecular mass 'ladder-like' bands characteristic of smooth LPS 


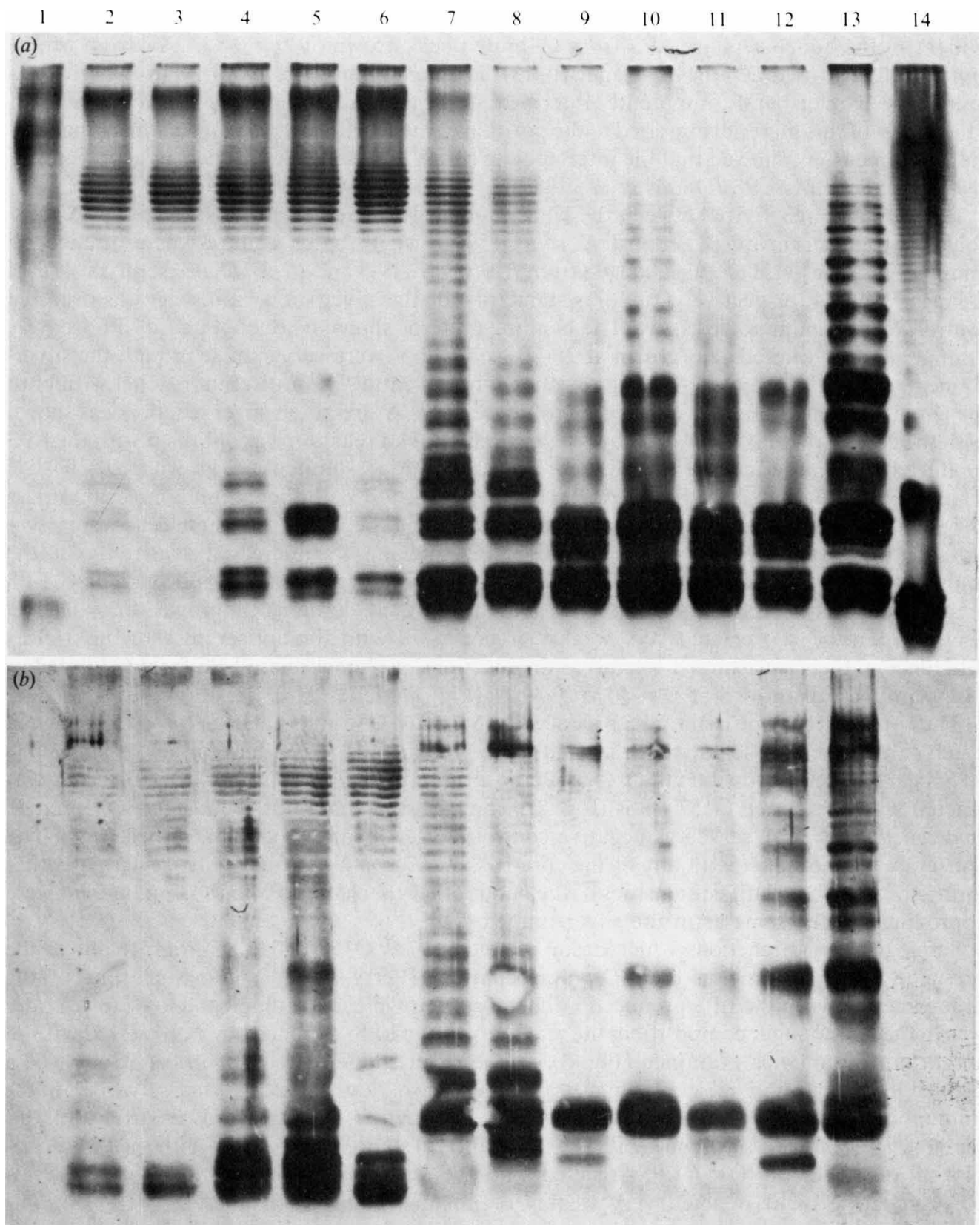

Fig. 1. SDS-PAGE analysis of purified LPS from $E$. coli O157. (a) Silver stained gel. (b) Immunoblot reacted with polyclonal rabbit antisera raised against phenol-killed $E$. coli O157. Lanes: 1, purified LPS of $B$. abortus; 2, 3, phenol-phase LPS from C-limited cells grown at $D=0 \cdot 1 \mathrm{~h}^{-1}$, two different experiments; 4 , phenol-phase LPS from C-limited cells grown at $D=0.4 \mathrm{~h}^{-1} ; 5$, phenol-phase LPS from $\mathrm{Mg}^{2+}$-limited cells grown at $D=0.4 \mathrm{~h}^{-1} ; 6$, phenol-phase LPS from $\mathrm{Mg}^{2+}$-limited cells grown at $D=0 \cdot 1 \mathrm{~h}^{-1} ; 7$, aqueous-phase LPS from $\mathrm{Mg}^{2+}$-limited cells grown at $D=0 \cdot 1 \mathrm{~h}^{-1} ; 8$, aqueous-phase LPS from C-limited cells grown at $D=0.4 \mathrm{~h}^{-1} ; 9$, phenol-phase LPS from C-limited cells grown at $D=0.8 \mathrm{~h}^{-1} ; 10,11,12$, aqueous-phase LPS from C-limited cells grown at $D=0.8 \mathrm{~h}^{-1}$, three different experiments; 13, aqueous-phase LPS from $\mathrm{Mg}^{2+-}$ limited cells grown at $D=0.4 \mathrm{~h}^{-1} ; 14$, purified LPS from $P$. haemolytica. 
containing $O$-polysaccharides of heterogeneous chain length, as well as lower molecular mass bands characteristic of rough LPS (lanes 2-6). Very little or no high molecular mass LPS was evident in the aqueous-phase LPS from C-limited cells grown at $D=0.8 \mathrm{~h}^{-1}$ or from $\mathrm{Mg}^{2+}$ limited cells grown at $D=0.4 \mathrm{~h}^{-1}$ (lanes 10-13). The predominant form of LPS from these cells stained as distinct bands, apparently intermediate in molecular mass. Re-electrophoresis, in which most of this material migrated to the position of the second lowest molecular mass band in the first dimension, showed that the intermediate bands represented multimers or aggregates of low-molecular mass LPS (Dodds et al., 1987).

The antigenic reactivity between the LPSs produced by chemostat-grown E. coli $\mathrm{O} 157$ and polyclonal antiserum raised against $E$. coli 0157 grown in batch culture was examined by immunoblotting (Fig. 1 b). Purified LPS from B. abortus $119-3$ and $P$. hemolytica serotype 4 (Fig. 1 , lanes 1 and 14 , respectively), used as standards for the silver stain, also served as negative controls for the immunoblot assay. The banding patterns shown by phenol-phase LPS from Climited or $\mathrm{Mg}^{2+}$-limited cells grown at $D=0.1$ or $0.4 \mathrm{~h}^{-1}$ were very similar in both the silverstained gel and the immunoblot (Fig. 1, lanes 2-6) indicating the antiserum reacted with both the $O$-polysaccharide and the core regions of these LPSs. A slightly stronger reaction was shown with the core of these LPSs. An equally strong immunoblot reaction was obtained with the LPS produced by C-limited cells grown at $D=0.8 \mathrm{~h}^{-1}$ and by $\mathrm{Mg}^{2+}$-limited cells grown at $D=0.4 \mathrm{~h}^{-1}$ which formed multimers on SDS-PAGE (Fig. 1b, lanes 9-13). Although high molecular mass $O$-polysaccharide bands could not be distinguished when the LPSs from these cells were silver stained, they were evident in the immunoblot, showing the increased sensitivity of the immunoblot technique (Fig. 1 $b$, lanes 9-13). The core region of all aqueous-phase LPS preparations and the core region of phenol-phase LPS from C-limited cells grown at $D=0.8 \mathrm{~h}^{-1}$ (Fig. 1 $b$, lanes 7-13) reacted very weakly or not at all with the antiserum showing a clear difference to the silver-stained gel and to the reactions of phenol-phase LPS from C-limited or $\mathrm{Mg}^{2+}$-limited cells grown at $D=0.1$ or $0.4 \mathrm{~h}^{-1}$ (Fig. 1b, lanes 2-6).

The $O$-polysaccharide of the LPS produced by $S$. landau $\mathrm{O} 30$ and that of $E$. coli $\mathrm{O} 157$ grown in batch culture are identical except that half the D-glucopyranosyl residues in the $S$. landau $\mathrm{O} 30$ LPS bear $O$-acetyl substituents at C-6 (Perry et al., 1986). Anti-Salmonella O30 serum was reacted with the E. coli O157 LPSs (Fig. 2). The two standard LPSs, S. adelaide O35 and $P$. hemolytica serotype 4, served as negative controls (Fig. $2 b$, lanes 1 and 14 , respectively). The antiserum did not react with any of the core LPSs of $E$. coli $\mathrm{O} 157$ but did react with all other forms of LPS. The relative intensities of the bands other than core LPS in the immunoblot were approximately the same as in the silver-stained gel.

Serological cross-reactions which occur between E. coli $\mathrm{O} 157$ and B. abortus are due to the presence of perosamine in their $O$-polysaccharides (Perry et al., 1986). Since one of the differences between the LPS produced by chemostat-grown $E$. coli at high and low growth rates was in the amino sugar composition, the reactivity of the LPSs produced by $E$. coli O157 with $B$. abortus antiserum was examined (Fig. 3). In the silver-stained gel, B. abortus LPS showed a blurred band of high molecular mass and another of low molecular mass, while in the immunoblot a much larger region stained, again showing the increased sensitivity of this method. $P$. hemolytica serotype 4 LPS (Fig. $3 b$, lane 14) showed no reaction with the antiserum. Not all of the $E$. coli O157 LPSs reacted with the antiserum. The high molecular mass $O$ polysaccharide bands reacted very weakly or not at all (Fig. $3 b$, lanes $2-4,10,13$ ). The multimeric LPS bands reacted much more strongly (Fig. 3b, lanes 5-7, 9, 11, 12). Again, the $E$. coli core LPSs did not react.

Anti-E. coli serum was absorbed with $E$. coli cells grown overnight in batch culture to remove antibodies specific for the $O$-polysaccharide containing 2-aminohexose. Cells grown in batch culture were previously found to produce smooth LPS with this $O$-polysaccharide (Perry et al., 1986). Absorbing the antiserum greatly reduced the reaction of the $O$-polysaccharide bands in the immunoblot (Fig. $4 b$, lanes $2-4,8$ ). This is most evident in the proteinase-K digested wholecell lysates (Fig. $4 b$, lane 8) of cells grown overnight in batch culture. High molecular mass 'ladder-like' bands characteristic of smooth LPS containing $O$-polysaccharides of heterogeneous 


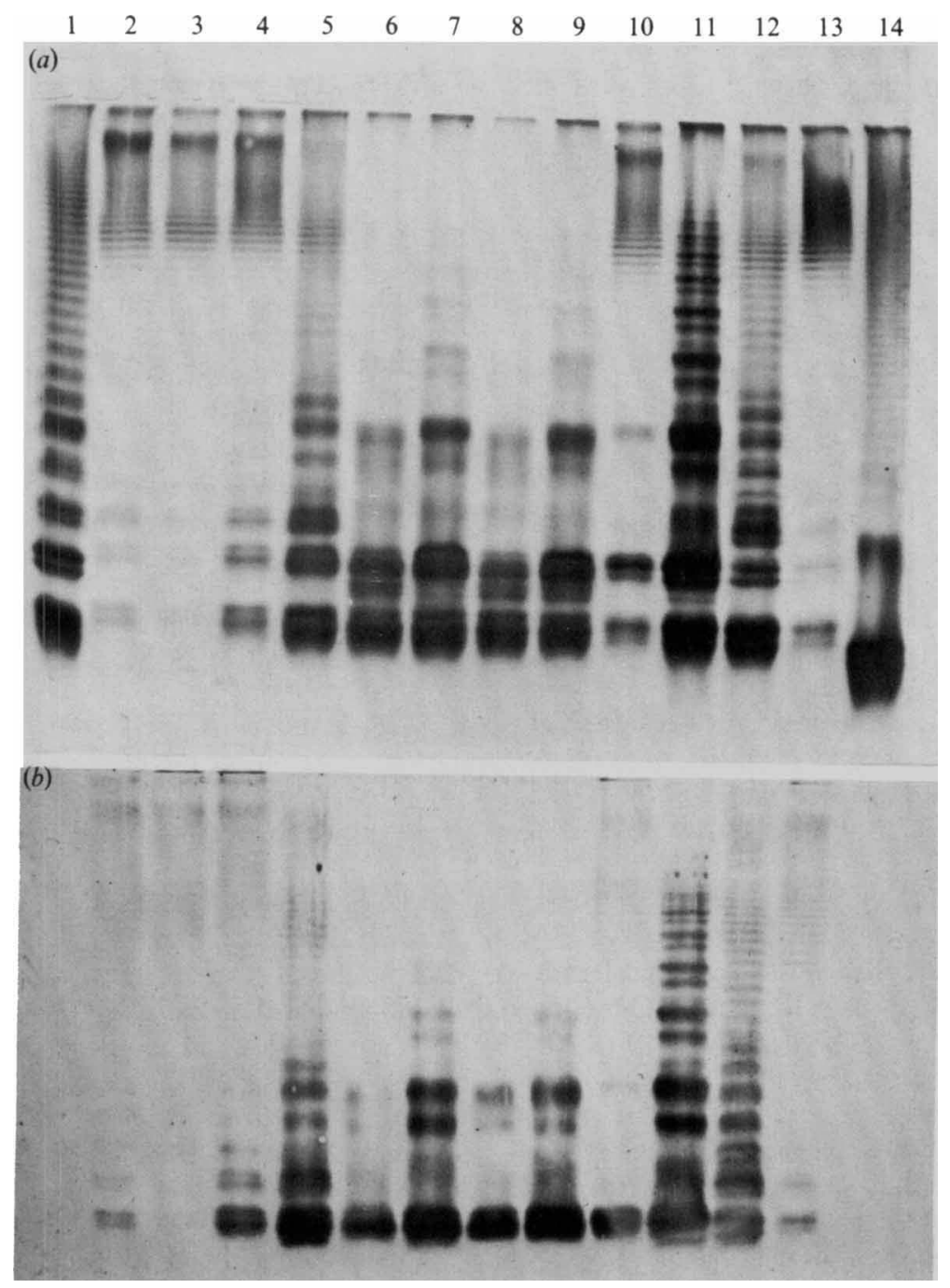

Fig. 2. SDS-PAGE analysis of purified LPS from E. coli O157. (a) Silver stained gel. (b) Immunoblot reacted with polyclonal rabbit antisera raised against Salmonella O30, absorbed to remove other agglutinins. Lanes: 1, purified LPS of $S$. adelaide O35; 2, 3, phenol-phase LPS from C-limited cells grown at $D=0 \cdot 1 \mathrm{~h}^{-1} ; 4$, phenol-phase LPS from C-limited cells grown at $D=0.4 \mathrm{~h}^{-1} ; 5$, aqueous-phase LPS from C-limited cells grown at $D=0.4 \mathrm{~h}^{-1} ; 6$, phenol-phase LPS from C-limited cells grown at $D=0.8 \mathrm{~h}^{-1} ; 7,8,9$, aqueous-phase LPS from C-limited cells grown at $D=0.8 \mathrm{~h}^{-1}$, three different experiments; 10 , phenol-phase LPS from $\mathrm{Mg}^{2+}$-limited cells grown at $D=0.4 \mathrm{~h}^{-1} ; 11$, aqueous-phase LPS from $\mathrm{Mg}^{2+}$-limited cells grown at $D=0.4 \mathrm{~h}^{-1} ; 12$, aqueous-phase LPS from $\mathrm{Mg}^{2+}$-limited cells grown at $D=0 \cdot 1 \mathrm{~h}^{-1} ; 13$, phenol-phase LPS from $\mathrm{Mg}^{2+}$-limited cells grown at $D=0 \cdot 1 \mathrm{~h}^{-1} ; 14$, purified LPS from $P$. haemolytica.

chain length were evident in the silver-stained LPS profile of these cells but they were very weak in the immunoblot. The material that did react in the immunoblot was of lower molecular mass than smooth LPS and could have been due to a reaction of the antiserum with some cellular proteins. Reactions of the low molecular mass LPS were unaffected by absorption of the antiserum. 


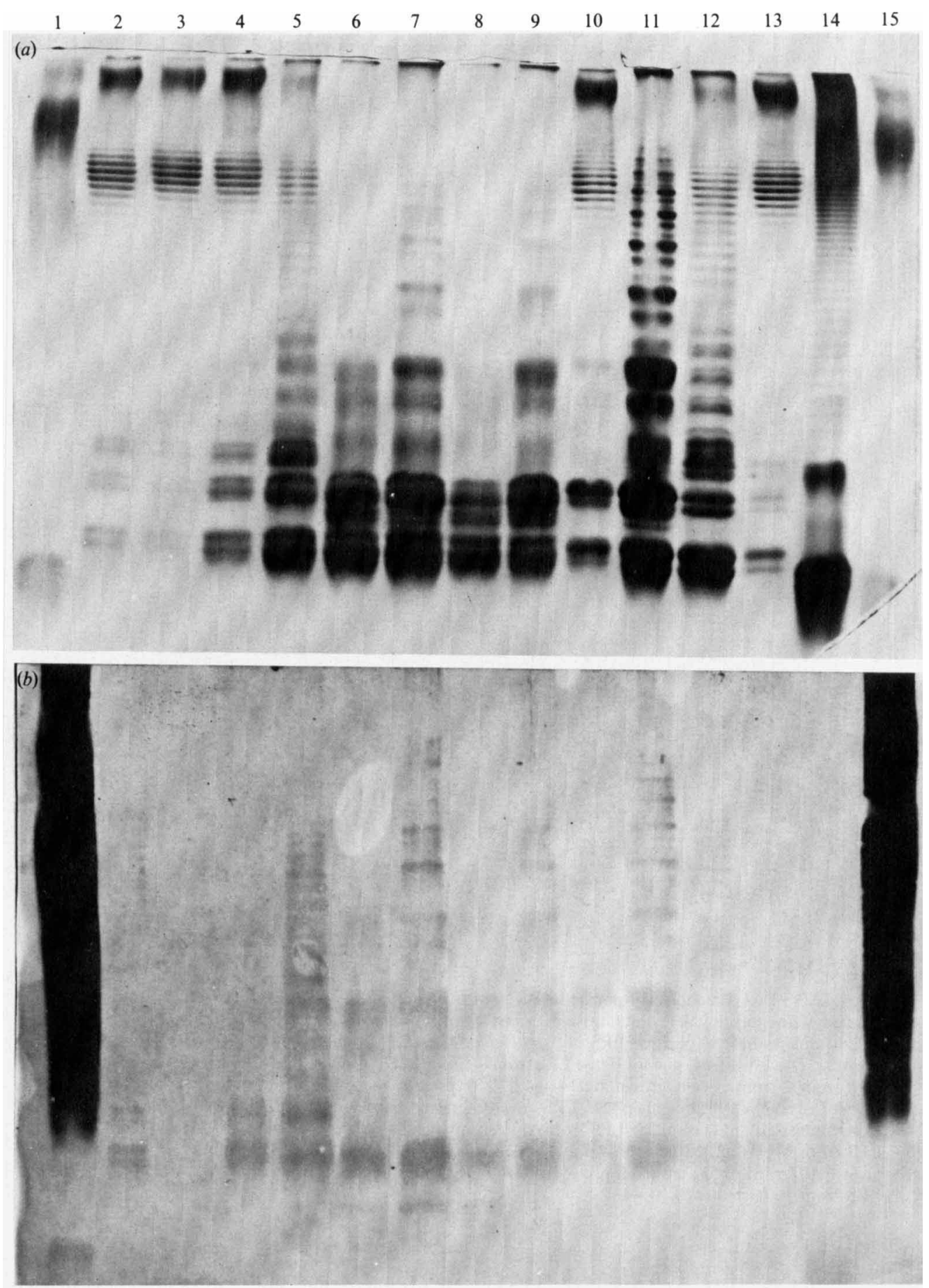

Fig. 3. SDS-PAGE analysis of purified LPS from E. coli O157. (a) Silver stained gel. (b) Immunoblot reacted with polyclonal bovine antisera raised against $B$. abortus. Lanes: 1, 14, purified LPS from $B$. abortus; 2,3 , phenol-phase LPS from C-limited cells grown at $D=0 \cdot 1 \mathrm{~h}^{-1}$, two different experiments; 4, phenol-phase LPS from C-limited cells grown at $D=0.4 \mathrm{~h}^{-1} ; 5$, aqueous-phase LPS from C-limited cells grown at $D=0.8 \mathrm{~h}^{-1} ; 6$, phenol-phase LPS from C-limited cells grown at $D=0.8 \mathrm{~h}^{-1} ; 7,8,9$, 

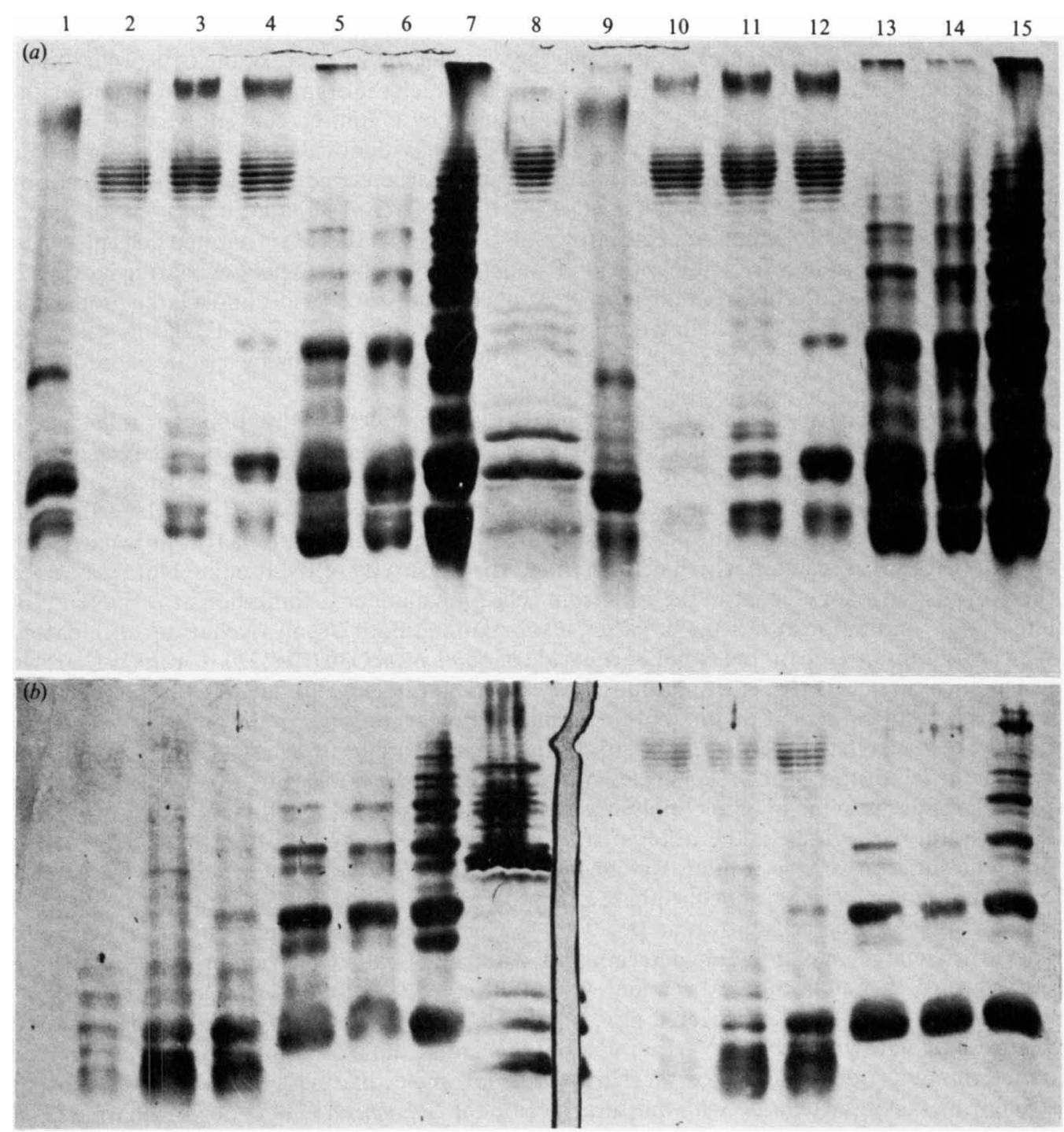

Fig. 4. SDS-PAGE analysis of LPS from E. coli O157. (a) Silver stained gel. (b) Immunoblot reacted with polyclonal rabbit antiserum raised against $E$. coli 0157 . Lanes $1-8$, reaction after absorption of antisera with live cells of $E$. coli O157. Lanes: 1, 9, purified LPS from $S$. adelaide $\mathrm{O} 35 ; 2,10$, phenolphase LPS from C-limited cells grown at $D=0 \cdot 1 \mathrm{~h}^{-1} ; 3,11$, phenol-phase LPS from C-limited cells grown at $D=0.4 \mathrm{~h}^{-1} ; 4,12$, phenol-phase LPS from $\mathrm{Mg}^{2+}$-limited cells grown at $D=0.4 \mathrm{~h}^{-1} ; 5,6,13$, 14, aqueous-phase LPS from C-limited cells grown at $D=0.8 \mathrm{~h}^{-1}$, two different experiments; 7,15 , aqueous-phase LPS from $\mathrm{Mg}^{2+}-$ limited cells grown at $D=0.4 \mathrm{~h}^{-1} ; 8$, proteinase-K digested whole cell lysates of E. coli $\mathrm{O} 157$.

aqueous-phase LPS from C-limited cells grown at $D=0.8 \mathrm{~h}^{-1}$, three different experiments; 10 , phenolphase LPS from $\mathrm{Mg}^{2+}$-limited cells grown at $D=0.4 \mathrm{~h}^{-1} ; 11$, aqueous-phase LPS from $\mathrm{Mg}^{2+}$-limited cells grown at $D=0 \cdot 4 \mathrm{~h}^{-1} ; 12$, aqueous-phase LPS from $\mathrm{Mg}^{2+}$-limited cells grown at $D=0 \cdot 1 \mathrm{~h}^{-1} ; 13$, phenol-phase LPS from $\mathrm{Mg}^{2+}$-limited cells grown at $D=0.1 \mathrm{~h}^{-1} ; 14$, purified LPS from $P$. haemolytica. 


\section{DISCUSSION}

In a previous report (Dodds et al., 1987) we showed that the structure of the LPS produced by chemostat-grown E. coli $\mathrm{O} 157$ depended on the rate at which the organism was grown and on the nutrient that was growth limiting. The LPS produced by C-limited cells grown at $D=0 \cdot 1$ or $0.4 \mathrm{~h}^{-1}$ and by $\mathrm{Mg}^{2+}$-limited cells grown at $D=0.1 \mathrm{~h}^{-1}$ was identical to that produced by batchgrown cells, the $O$-polysaccharide of which has been characterized as a linear polysaccharide having the structure [-3)- $\alpha$-D-GalNAc $p-(1 \rightarrow 2)-\alpha-\mathrm{D}-\operatorname{PerNAc} p-(1 \rightarrow 3)-\alpha-\mathrm{L}-\mathrm{Fuc} p-(1 \rightarrow 4)-\beta$-D-Glc $p$ $(1-]_{n}$ (Perry et al., 1986). C-limited cells grown at $D=0.8 \mathrm{~h}^{-1}$ and $\mathrm{Mg}^{2+}$-limited cells grown at $D=0.4 \mathrm{~h}^{-1}$ produced a very small amount of smooth LPS with an $O$-polysaccharide lacking 2aminohexose, thus differing from the aforementioned $O$-polysaccharide, and a large proportion of low molecular mass LPS which tended to form multimers on SDS-PAGE. In this study, we have further characterized the LPSs produced by E. coli 0157 using electrophoresis and immunoblotting.

The $O$-polysaccharide from cells of $E$. coli $\mathrm{O} 157$ grown under C-limitation at $D=0.8 \mathrm{~h}^{-1}$ or under $\mathrm{Mg}^{2+}$-limitation at $D=0.4 \mathrm{~h}^{-1}$ differs chemically from, but appears to have some of the same antigenic determinants as, the $O$-polysaccharide from cells grown in batch culture or under C-limitation at $D=0.1$ and $0.4 \mathrm{~h}^{-1}$ or under $\mathrm{Mg}^{2+}$-limitation at $D=0.1 \mathrm{~h}^{-1}$. Both $O$ polysaccharides reacted with the polyclonal serum prepared against $E$. coli $\mathrm{O} 157$ grown in batch culture (Fig. $1 b$ ), a reaction which demonstrated the sensitivity of the immunoblot assay since these bands were not evident in the LPS from cells grown under C-limitation at $D=0.8 \mathrm{~h}^{-1}$ or under $\mathrm{Mg}^{+2}$-limitation at $D=0.4 \mathrm{~h}^{-1}$ after silver staining. Both $O$-polysaccharides also reacted with antiserum specific for the $O$-polysaccharide of Salmonella O30 (Fig. 2b). E. coli O157 grown in batch culture cross reacts with group N Salmonella (antigen O30) due to $O$-polysaccharides which are identical except that half of the D-glucopyranosyl residues in the group N Salmonella LPS are 6-O-acetylated (Perry et al., 1986). Antiserum raised against $B$. abortus gave very little or no reaction with the $O$-polysaccharides produced by $E$. coli $\mathrm{O} 157$ (Fig. $3 b$ ) even though the presence of perosamine in both $O$-polysaccharides can cause cross reactions (Perry et al., 1986). Because the reactivities of the different $O$-polysaccharides produced by $E$. coli $\mathrm{O} 157$ to the different antisera were so similar, we conclude that the differences between them are subtle.

The low molecular mass aqueous-phase LPS produced by C-limited cells grown at $D=0.8 \mathrm{~h}^{-1}$ and by $\mathrm{Mg}^{2+}$-limited cells grown at $D=0.4 \mathrm{~h}^{-1}$ which formed multimers on SDS-PAGE also appears to share some antigenic determinants with the $O$-polysaccharide produced by $E$. coli O157 grown in batch culture or under C-limitation at $D=0.1$ or $0.4 \mathrm{~h}^{-1}$ or under $\mathrm{Mg}^{2+}$. limitation at $D=0 \cdot 1 \mathrm{~h}^{-1}$. It reacted just as strongly as $O$-polysaccharide with antisera raised against batch-grown $E$. coli $\mathrm{O} 157$ (Fig. 1 b), but this antiserum may contain antibodies directed at determinants other than $O$-polysaccharide. The low molecular mass LPS also reacted just as strongly as $O$-polysaccharide with antisera specific for Salmonella $\mathrm{O} 30 \mathrm{O}$-polysaccharide (Fig. $2 b$ ). However, some differences in reactivities were apparent. While the $O$-polysaccharides reacted very weakly or not at all with antiserum raised against $B$. abortus, the low molecular mass LPS gave a fairly strong reaction (Fig. $3 b$ ). Since the $B$. abortus $O$-polysaccharide is a homopolymer of perosamine this sugar is likely to be present in this LPS. While the normal $E$. coli $\mathrm{O} 157 \mathrm{O}$-polysaccharide also contains this sugar, it did not react, thus the particular antigenic determinant may be more accessible in the low molecular mass LPS. Absorption of the antiserum raised against $E$. coli $\mathrm{O} 157$ with homologous cells reduced reactivity with $O$ polysaccharide but not with the low molecular mass LPS (Fig. $4 b$ ). If, after absorption, antibody was no longer present in excess, a more exposed site on the low molecular mass LPS would be favoured. The reactivity of the low molecular mass LPS with antisera specific for, or known to cross react with, the $O$-polysaccharide produced by batch-grown $E$. coli $\mathrm{O} 157$ confirms results of two-dimensional SDS-PAGE that this material represents semi-rough LPS having one repeat unit of $O$-polysaccharide attached to core LPS.

The fastest migrating band of $E$. coli O157 LPS, representing core LPS (Goldman \& Leive, 1980; Munford et al., 1980; Palva \& Makela, 1980), unexpectedly showed differences in reactivity to the antiserum raised against $E$. coli 0157 (Fig. $1 b$ ). Core LPS from all phenol preparations except for that from C-limited cells grown at $D=0 \cdot 8 \mathrm{~h}^{-1}$, reacted with the 
antiserum whereas the core LPS from aqueous-phase preparations did not. Because the structure of the core is thought to be essentially conserved (Mayer et al., 1985; Luderitz et al., 1982) and because these bands all showed the same mobility on SDS-PAGE, the differences are probably the result of minor differences in substitutions.

In our previous study (Dodds et al., 1987), we found that a much higher proportion of rough LPS was produced by E. coli $\mathrm{O} 157$ at high growth rates. Such changes have been related by others to a decrease in the activity of R-core- $O$-polysaccharide ligase relative to the other enzymes involved in LPS biosynthesis (McConnell \& Wright, 1979). The immunoblot assay has shown that the different $O$-polysaccharides produced by $E$. coli $\mathrm{O} 157$ have some antigenic determinants in common and the differences between the two are probably minor, possibly involving differences in modification of the polysaccharide after its assembly. The low molecular mass LPS produced by C-limited cells grown at $D=0.8 \mathrm{~h}^{-1}$ and by $\mathrm{Mg}^{2+}$-limited cells grown at $D=0.4 \mathrm{~h}^{-1}$ represents semi-rough LPS (core LPS plus only one repeat unit of $O$ polysaccharide) suggesting differences in the polymerization of repeating units. Thus, results from this study suggest that other aspects of the biosynthesis of LPS are also affected by growth conditions.

\section{REFERENCES}

Caroff, M., Bundle, D. R. \& Perry, M. B. (1984) Structure of the $O$-chain of the phenol-phase soluble cellular lipopolysaccharide of Yersinia enterocolitica serotype O:9. European Journal of Biochemistry 139, 195-200.

Chart, H., Shaw, D. H., Ishiguro, E. E. \& Trust, T. J. (1984). Structural and immunochemical homogeneity of Aeromonas salmonicida lipopolysaccharide. Journal of Bacteriology 158, 16-22.

Dodds, K. L., Perry, M. B. \& McDonald, I. J. (1987). Alterations in lipopolysaccharide produced by chemostat-grown Escherichia coli $\mathrm{O} 157: \mathrm{H} 7$ as a function of growth rate and growth-limiting nutrient. Canadian Journal of Microbiology 33, 452-458.

Dooley, J. S. G., Lallier, R., Shaw, D. H. \& Trust, T. J. (1985). Electrophoretic and immunochemical analyses of the lipopolysaccharides from various strains of Aeromonas hydrophila. Journal of Bacteriology 164, 263-269.

Goldman, R. C. \& Leive, L. (1980). Heterogeneity of antigenic-side-chain length in lipopolysaccharide from Escherichia coli $\mathrm{O} 111$ and Salmonella typhimurium LT2. European Journal of Biochemistry 107, 145153.

HitchCock, P. J. \& BRown, T. M. (1983). Morphological heterogeneity among Salmonella lipopolysaccharide chemotypes in silver-stained polyacrylamide gels. Journal of Bacteriology 154, 269-277.

Johnson, K. G. \& Perry, M. B. (1976). Improved techniques for the preparation of bacterial lipopolysaccharides. Canadian Journal of Microbiology 22, 29-34.

DeJongh-Leuvenink, J., VReede, R. W., Marcelis, J. H., DEVOS, M. \& VERHOEF, J. (1985). Detection of antibodies against lipopolysaccharides of Escherichia coli and Salmonella $\mathrm{R}$ and $\mathrm{S}$ strains by immunoblotting. Infection and Immunity 50, 716-720.

LAEMMLI, U. K. (1970). Cleavage of structural proteins during the assembly of the head of bacteriophage T4. Nature, London 227, 680-685.

Luderitz, O., Freudenberg, M. A., Galanos, C., LehMAN, V., ReITSCHEL, E. T. \& SHAW, D. H. (1982). Lipopolysaccharides of Gram-negative bacteria.
Current Topics in Membranes and Transport 17, 79151.

Mayer, H., Tharanathan, R. N. \& Weckesser, J. (1985). Analysis of lipopolysaccharides of Gramnegative bacteria. Methods in Microbiology 18, 157 207.

MCCONNELl, M. \& WRIGHT, A. (1979). Variation in the structure and bacteriophage-inactivating capacity of Salmonella anatum lipopolysaccharide as a function of growth temperature. Journal of Bacteriology 137, 746-751.

Munford, R. S., Hall, C. L. \& Rick, P. D. (1980). Size heterogeneity of Salmonella typhimurium lipopolysaccharides in outer membranes and culture supernatant membrane fragments. Journal of Bacteriology 144, 630-640.

Palva, E. T. \& Makela, P. H. (1980). Lipopolysaccharide heterogeneity in Salmonella typhimurium analyzed by sodium docecyl sulfate/polyacrylamide gel electrophoresis. European Journal of Biochemistry 107, 137-143.

Perry, M. B. \& Babiuk, L. A. (1984). Structure of the polysaccharide chain of Pasteurella haemolytica (serotype 4) lipopolysaccharide. Canadian Journal of Biochemistry and Cell Biology 62, 108-114.

PerRy, M. B., MaCLean, L. \& Griffith, D. W. (1986). Structure of the O-chain polysaccharide of the phenol-phase soluble lipopolysaccharide of Escherichia coli $\mathrm{O}: 157: \mathrm{H} 7$. Canadian Journal of Biochemistry and Cell Biology 64, 21-28.

Towbin, H., Staehelin, T. \& Gordon, J. (1979). Electrophoretic transfer of proteins from polyacrylamide gels to nitrocellulose sheets: procedure and some applications. Proceedings of the National Academy of Sciences of the United States of America 76, $4350-4354$.

TSAI, C. M. \& Frasch, C. E. (1982). A sensitive silver stain for detecting lipopolysaccharides in polyacrylamide gels. Analytical Biochemistry 119, 115-119.

WeSTPHAL, O. \& J JNN, K. (1965). Bacterial lipopolysaccharides. Extraction with phenol-water and further applications of the procedures. Methods in Carbohydrate Chemistry 5, 83-91. 